Article

\title{
Evaluation of Dispersed Alkaline Substrate and Diffusive Exchange System Technologies for the Passive Treatment of Copper Mining Acid Drainage
}

\author{
Alex Schwarz ${ }^{1, *}$, Iván Nancucheo ${ }^{2}{ }^{\circledR}$, Maria A. Gaete ${ }^{1}$, Diego Muñoz ${ }^{1}$, Pamela Sanhueza ${ }^{1}$, \\ Martin Torregrosa ${ }^{1}$, Tobias Rötting ${ }^{3}$, Gordon Southam ${ }^{4} \mathbb{D}$ and Marcelo Aybar ${ }^{1}$ \\ 1 Departamento de Ingeniería Civil, Universidad de Concepción, Edmundo Larenas 219, Concepción 4070386, \\ Chile; alemag.4467@gmail.com (M.A.G.); dimunoz@udec.cl (D.M.); pamsanhueza@udec.cl (P.S.); \\ mtorregrosa76@gmail.com (M.T.); maybar@udec.cl (M.A.) \\ 2 Facultad de Ingeniería y Tecnología, Universidad San Sebastián, Lientur 1457, Concepción 4080871, Chile; \\ ivan.nancucheo@uss.cl \\ 3 Golder Associates (UK) Ltd, Bourne End SL8, UK; troetting@gmail.com \\ 4 School of Earth \& Environmental Sciences, University of Queensland, St Lucia 4067, Australia; \\ g.southam@uq.edu.au \\ * Correspondence: alexschwarz@udec.cl
}

Received: 13 February 2020; Accepted: 13 March 2020; Published: 18 March 2020

\begin{abstract}
The study evaluates the performance of the novel ADES (alkaline diffusive exchange System), SDES (sulfidogenic diffusive exchange system) and DAS (Dispersed Alkaline Substrate) technologies for the passive treatment of high-strength acid mine drainage (AMD) from copper mining ( $\mathrm{pH}$ 3, $633 \mathrm{mg} \mathrm{Cu} \mathrm{L}^{-1}$ ). The chemical DAS and ADES prototypes showed the best performance in the removal of $\mathrm{Cu}, \mathrm{Al}$, and $\mathrm{Zn}(98-100 \%)$, while the biochemical SDES reactors achieved a high sulfate removal rate (average of $0.28 \mathrm{~mol} \mathrm{~m}^{-3}$ day $^{-1}$ ). Notably, the DES technology was effective in protecting the sulfate-reducing communities from the high toxicity of the AMD, and also in maintaining bed permeability, an aspect that was key in the ADES reactor. The DAS reactor showed the highest reactivity, accumulating the metallic precipitates in a lower reactor volume, allowing to conclude that it requires the lowest hydraulic residence time among all the reactors. However, the concentration of precipitates resulted in the formation of a hardpan, which may trigger the need of removing it to avoid compromising the continuity of the treatment process. This study suggests the development of new treatment alternatives by combining the strengths of each technology in combined or serial treatments.
\end{abstract}

Keywords: acid mine drainage; copper; passive treatment; sulfate reduction; diffusive exchange; dispersed alkaline substrate

\section{Introduction}

Acid mine drainage (AMD) is an effluent from the mining industry generated by the interaction of mining waste derived from the extraction and processing of the ore (waste rock deposits and tailing dams), with environmental factors, mainly water, oxygen and microorganisms [1-3]. The acidic $\mathrm{pH}$ between -3.6 and 6 and the high concentrations of sulfate and heavy metals that characterize AMD are the result of oxidation reactions of sulfur minerals and leaching of associated elements [4]. In the case of Chile, the most significant sources of AMD are the cordilleran copper deposits during snowmelt, which are located in the central zone of the country. Recently, research on its treatment has increased [5-9]. A particularity of this AMD is that it presents high concentrations of copper, which can be recovered economically [8]. In the United States, copper mining is significant in Utah and New Mexico, where AMD is also being investigated $[10,11]$. In Canada, the Ontario region has a high density of small 
copper deposits, and AMD is present in a vast area [12]. In Spain, the Iberian Pyrite Belt has hundreds of abandoned deposits that release AMD, and remediation by traditional methods has been ineffective, motivating research into new treatments [1].

AMD treatment technologies are classified as active and passive. Passive systems are characterized by low energy and chemical consumption, and low operational control and maintenance requirements, which makes them particularly attractive for remote sites or abandoned mines, and in the closure phase of projects $[13,14]$. Passive treatments are often designed to pass the AMD through a reactive bed of organic materials, generally residues (e.g., wood chips, manure, compost), and alkaline materials (e.g., limestone, sea shells, ash). These two types of substrate can be used separately as in an anoxic limestone drain (ALD), which uses only alkaline materials; can be mixed in a homogeneous substrate in a biochemical reactor [15]; or arranged sequentially as in a reducing and alkalinity producing system (RAPS) [16]. The alkaline materials react with the acidity of the AMD, causing the increase of $\mathrm{pH}$ and the precipitation of metals as hydroxides or carbonates, while the organic material promotes the biological reduction of sulfate, also a proton consuming reaction, while the produced sulfide forms sparingly soluble complexes with most toxic metals.

In biological treatment of AMD, the reactive organic material promotes the development of a microbial consortium that hydrolyzes and ferments complex organic compounds such as celluloses and hemicelluloses to electron donors for sulfate-reducing bacteria (SRB), e.g., acetic acid, and butyric acid [14,17-19]. SRB are essential to AMD treatment $[19,20]$ by using sulfate as the final electron acceptor and reducing it to sulfide. When the acidity of the AMD is excessive, the organic mixture can also be supplemented with alkaline substrates. The design of the passive biological reactors is based on the sulfate reduction rate $\left(0.2-0.3 \mathrm{~mol} \mathrm{~m}^{-3}\right.$ day $\left.^{-1}\right)$. Based on this rate, the necessary hydraulic residence time (HRT) can be calculated to reach the desired degree of metal removal [15], with the HRT of biochemical reactors being in the order of days.

The ability of alkaline substrates to neutralize acidity is much higher than that of organic substrates, so predominantly chemical treatment systems such as ALDs are most commonly used to treat AMD passively. However, the capacity of chemical systems to remove sulfate is minimal, and therefore also biological systems are employed. Due to the rapid kinetics of chemical neutralization reactions, purely chemical systems are designed based on HRT in the order of hours (e.g., USEPA [21] recommends 15 hours for ALD systems).

Current research on passive bioreactors has focused on the study of the microbial communities involved [22,23]. Environmental factors (HRT, organic source, pH, metals, sulfates, and sulfides) have a significant impact on the composition of microbial communities, and the study of reactor microorganisms is critical for the selection of phylogenetic groups as inoculum [24]. Despite this, passive bioreactors are considered less robust than chemical systems because the characteristics of AMD are variable, and microbial communities can be particularly affected by low $\mathrm{pH}$ and temperatures, and toxic concentrations of metals [25], which has stimulated the development of sulfidogenic diffusion exchange systems (SDES) $[6,9,26]$. A distinctive characteristic of DES systems are exclusive zones for the flow of water through the bed (e.g., screen tubes or layers of sand), in order to favor the permeability of the bed and the protection of microbial communities within reactive, less permeable layers, from direct contact with the toxic components of the contaminated water. Although the technology is still in development, it has demonstrated the ability to treat concentrated AMD, maintain a diverse microbial community, and sustain hydraulic permeability. Pérez et al. [5] implemented three SDES reactors to treat AMD with high copper concentration $\left(528 \mathrm{mg} \mathrm{L}^{-1} \mathrm{Cu}\right.$ ) using screen tubes to convey the AMD through the reactive bed, achieving both sulfate and metal removal rates of up to $0.33 \mathrm{~mol}$ $\mathrm{m}^{-3}$ day $^{-1}$ (99\% metal removal). High copper accumulation was detected at the bottom of the screen tubes, which opens the possibility to recover commercially valuable materials in passive reactors. Torregrosa et al. [9] also treated concentrated copper AMD (633.5 $\left.\mathrm{mg} \mathrm{L}^{-1} \mathrm{Cu}\right)$ with SDES permeable reactive barrier (PRB) bench-scale reactors, attaining metal removal efficiencies of practically $100 \%$ at high sulfate removal rates $\left(0.44-0.47 \mathrm{~mol} \mathrm{~m}^{-3}\right.$ day $\left.^{-1}\right)$. The study focused on the thickness of SDES 
PRB layers, showing that the correct layer thickness is critical for the proper functioning of SDES PRBs since an excessively thin layer does not allow the establishment of bioprotecting gradients, while an excessively thick one causes diffusion to control the treatment efficiency.

On the other hand, the dispersed alkaline system (DAS) is an important development in terms of passive technologies for AMD chemical treatment [27-30]. The DAS consists of a matrix of wood chips mixed with adhered fine particles of limestone to increase the reactivity of the limestone and reduce the problems of passivation and clogging [29]. Wood particles provide high permeability and large pores to reduce clogging problems, while the small grain size of the limestone provides a large reactive area to increase reactivity and decrease passivation. Rötting et al. [31] treated highly acidic AMD (1350-2300 $\mathrm{mg} \mathrm{L}^{-1}$ as $\left.\mathrm{CaCO}_{3}\right)$ in column DAS reactors, removing almost all metals and 900-1600 $\mathrm{mg} \mathrm{L}^{-1}$ as $\mathrm{CaCO}_{3}$ acidity, more than three times what a conventional passive system achieves (e.g., $300 \mathrm{mg} \mathrm{L}^{-1}$ alkalinity as $\mathrm{CaCO}_{3}$ in ALDs). Another DAS was implemented in the field, a variant that uses $\mathrm{MgO}$ instead of limestone, designed to remove divalent metals [32]. The MgO-DAS removed all acidity (1404-1609 $\mathrm{mg} \mathrm{L}^{-1} \mathrm{CaCO}_{3}$ ) and almost all toxic metals. However, at high influent loadings of metals, a hardpan forms that can clog reactors even in a DAS system [29], which suggests evaluating the application of diffusive exchange technology in chemical reactors; for example, by incorporating screen tubes to ensure the uninterrupted transport of AMD through beds of alkaline substrates. This novel technology, alkaline diffusive exchange system (ADES), was evaluated for the first time in this research, with limestone sand $(1 \mathrm{~mm}<\mathrm{d}<4.75 \mathrm{~mm})$ as the reactive substrate.

Although there have been remarkable advances in the development of new passive technologies, comparative studies that evaluate them under similar conditions are lacking. Accordingly, the objective of this study was to evaluate three emerging passive technologies, SDES, DAS, and ADES, in the treatment of concentrated AMD from copper mining. We fed all reactors with the same synthetic AMD, periodically monitoring critical effluent parameters to establish objective comparisons. The reacted substrates were investigated to establish metal mass balances and confirm the processes that occurred during the experiment.

\section{Materials and Methods}

\subsection{Reactor Set Up and Operation}

Four prototypes (called reactors A, B, C, and D) (Figure 1), made of PVC columns, 1.5 meters high and $20 \mathrm{~cm}$ outside diameter, were implemented in a roofed outdoor enclosure. All had in common a $20 \mathrm{~cm}$ layer of coarse sand (0.5-5 mm grain size) at the base, a $100 \mathrm{~cm}$ reactive substrate bed, a $10 \mathrm{~cm}$ layer of coarse sand (0.5-5 mm grain size) on top, and a $10 \mathrm{~cm}$ zone of free water. Three of these prototypes (reactors A, B, and D) worked with DES technology, including a metal screen tube attached to their bases, of $6 \mathrm{~cm}$ internal diameter. The fourth prototype corresponded to a DAS reactor (reactor C). Of the three DES prototypes, two were SDES replicas (reactors A and B), while the other was an ADES (reactor D). Chemical reactors $C$ and D were equipped with five sampling ports at 10, 20, 40, 60, and $90 \mathrm{~cm}$ distance from the entrance of the flow, above the first layer of sand (Figure 1b). 

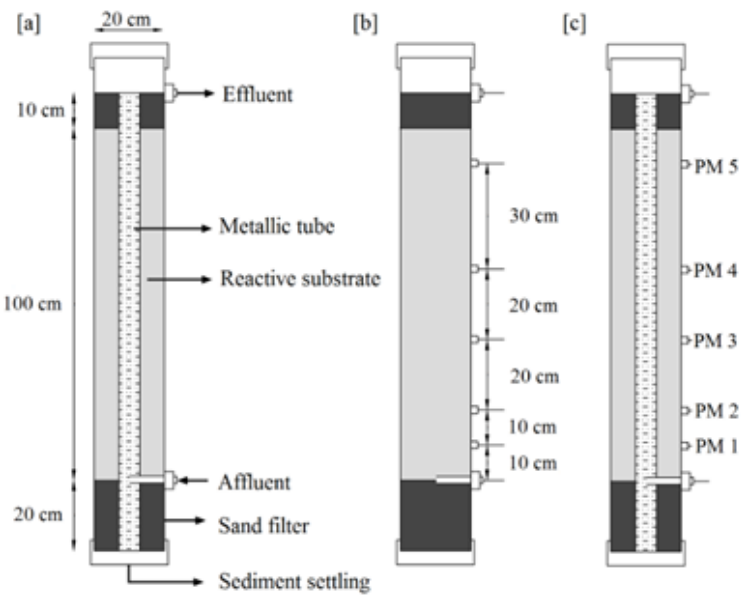

Figure 1. Design of passive reactor prototypes: (a) sulfidogenic diffusion exchange systems (SDES) replicas without sampling ports and with metal screens (reactors A and B); (b) The dispersed alkaline system (DAS) with sampling ports and without a metal screen (reactor C); (c) The alkaline diffusive exchange system (ADES) with sampling ports and a metal screen (reactor D).

The reactive bed volume of DES A, B, and C reactors was 26 liters. The reactive material weight distribution (wet weight) of SDES A and B reactors was 13\% fresh cow manure, 23\% leaf compost, 37\% fibers of non-delignified cellulose, and $26 \%$ powdered limestone (Table 1 ). The inoculum of the SDES reactors consisted of $8 \mathrm{~L}$ anaerobic digester content of the local sewage treatment plant. On the other hand, the ADES D chemical reactor was filled with a mixture of limestone sand $(1-4.75 \mathrm{~mm})(54 \% \mathrm{w} / \mathrm{w})$ and coarse sand $(1-4.75 \mathrm{~mm})(46 \% \mathrm{w} / \mathrm{w})$. The reactive bed volume of the DAS (reactor C) was $29.3 \mathrm{~L}$. The DAS reactor was filled with a mixture of wood chips (average thickness and length of $0.7 \mathrm{~mm}$ and $31.6 \mathrm{~mm}$, respectively), and fine limestone (D30 $=0.078 \mathrm{~mm}, \mathrm{D} 50=0.19 \mathrm{~mm}, \mathrm{D} 60=0.244 \mathrm{~mm})$ in a proportion of $12 \%$ and $88 \%$ by weight, respectively.

Table 1. Prototype reactive mixture composition ${ }^{1}$.

\begin{tabular}{ccccc}
\hline Substrate & $\begin{array}{c}\text { Reactor A } \\
\text { (SDES) }\end{array}$ & $\begin{array}{c}\text { Reactor B } \\
\text { (SDES) }\end{array}$ & $\begin{array}{c}\text { Reactor C } \\
\text { (DAS) }\end{array}$ & $\begin{array}{c}\text { Reactor D } \\
\text { (ADES) }\end{array}$ \\
\hline Fibers of forest origin & $4.48 \mathrm{~kg}$ & $4.05 \mathrm{~kg}$ & - & - \\
Leaf compost & $2.84 \mathrm{~kg}$ & $2.57 \mathrm{~kg}$ & - & - \\
Cow manure & $1.63 \mathrm{~kg}$ & $1.48 \mathrm{~kg}$ & - & - \\
Pulverized calcite & $3.15 \mathrm{~kg}$ & $2.85 \mathrm{~kg}$ & $14.9 \mathrm{~kg}$ & - \\
Bacterial inoculum & $8.17 \mathrm{~L}$ & $7.38 \mathrm{~L}$ & - & - \\
Calcite sand (1-4.75 mm) & - & - & - & $20.05 \mathrm{~kg}$ \\
Wood chips & - & - & - & - \\
Coarse sand $(1-4.75 \mathrm{~mm})$ & - & - & - & $17.38 \mathrm{~kg}$ \\
\hline
\end{tabular}

After filling, SDES reactors A and B were left in batch (phase 1) with an acid solution of $\mathrm{Na}_{2} \mathrm{SO}_{4}$ (2574 $\mathrm{mg} \mathrm{L}^{-1} \mathrm{SO}_{4}, \mathrm{pH} 3.3$ ) for 40 days (days 1-40) until evidence of sulfate reduction was detected. Subsequently, these two reactors were fed the same sulfate-bearing solution at a flow rate of $0.69 \mathrm{~L}$ day $^{-1}$ (phase 2) during 38 days (days 41-78). Then (phase 3 ), all prototypes operated for the following 215 days (days 79-293) with synthetic AMD (601 mg L ${ }^{-1} \mathrm{Cu}, 96 \mathrm{mg} \mathrm{L}^{-1} \mathrm{Al}, 61 \mathrm{mg} \mathrm{L}^{-1} \mathrm{Zn}, 153 \mathrm{mg}$ $\mathrm{L}^{-1} \mathrm{Mn}, 164 \mathrm{mg} \mathrm{L}^{-1} \mathrm{Ca}, 7 \mathrm{mg} \mathrm{L}^{-1} \mathrm{Fe}(\mathrm{II}), 2,533 \mathrm{mg} \mathrm{L}^{-1} \mathrm{SO}_{4}$, and $\mathrm{pH}$ 2.8-3.1) at the same flow rate of phase 2. The AMD, characteristic of large copper mines in Chile [8], was prepared weekly using metal sulfates, and the $\mathrm{pH}$ adjusted with $\mathrm{HCl}$. The HRT for the four reactors was 21 days assuming a substrate porosity of $50 \%$. This residence time was defined to achieve a high metal removal in the SDES reactors. Although oversized for chemical reactors, the unique HRT resulted in the same metal load 
for all reactors, allowing subsequently to perform a comparative analysis of the effect and fate of these metals. The flow was ascending to minimize the overflow of the reactor by clogging, by a peristaltic pump, Masterflex 7523-90, Cole Parmer, Vernon Hills, USA, and run using Masterflex tubing.

\subsection{Water Sampling and Analysis}

During phases 1 and 2, column effluent samples were collected weekly to determine $\mathrm{pH}$, ORP, and concentrations of dissolved $\mathrm{SO}_{4}{ }^{2-}$ (Sulfaver, $\mathrm{HACH}$, Loveland, USA. Method $4500 \mathrm{E}, \mathrm{APHA}$ [33]) and total sulfide (Methylene blue, HACH, Loveland, USA. Method 4500-S2-D, APHA [33]). The samples were filtered $(0.45 \mu \mathrm{m})$ immediately after sampling to measure $\mathrm{pH}$ and ORP (Orion $370 \mathrm{pH} / \mathrm{mV}$ meter, Thermo Fisher Scientific, Waltham, USA). The $\mathrm{pH}$ electrode (Thermo Fisher Scientific, Waltham, USA) was calibrated using standard $\mathrm{pH} 4.0, \mathrm{pH} 7.0$, and $\mathrm{pH} 12.0$ buffers, and the ORP electrode ( $\mathrm{Ag} / \mathrm{AgCl}$ reference, Thermo Fischer Scientific, Waltham, USA) was checked using Zobell's solution. Samples of both influent and effluent were taken weekly (days 1-209), and then they were taken every two weeks (days 210-293). During the experiments with AMD (phase 3), metals ( $\mathrm{Cu}, \mathrm{Zn}, \mathrm{Fe}, \mathrm{Ca}$ and $\mathrm{Al}$ ) were also measured in filtered samples of influent, effluent and intermediate ports (reactors $C$ and D) by atomic absorption spectroscopy (AAS; Analyst 400, Perkin Elmer, Waltham, USA). Intermediate ports of reactors $C$ and D were sampled every two weeks from day 132 to 293 and from day 210 to 293, respectively. Likewise, samples of pore water were also extracted from the reactive material from reactors $A$ and $B$ to a depth of $40 \mathrm{~cm}$ at the end of the experiment, inserting from the surface a $3 \mathrm{~mm}$ diameter stainless steel tube connected to a syringe.

\subsection{Solids Sampling and Mineralogy}

The metal content and the mineralogy of the precipitates associated with the spent substrate and those sedimented to the bottom of the screen tubes were analyzed. Peristaltic pumps were used to extract sedimented precipitates. For the extraction of substrate samples, the reactors were opened longitudinally, and a minimum of 5 heights coinciding with the liquid sampling points sampled. Additionally, to observe the effect of DES on horizontal variability, samples were taken at different distances from the screen $(0-1.5,1.5-3.5,3.5-6.5 \mathrm{~cm})$. In the case of $C$ and $D$ reactors, samples were also taken at additional heights, with more precision in the first $10 \mathrm{~cm}$ of the substrate where steep chemical gradients were expected to form. As the substrates in the mixtures were heterogeneous, samples were homogenized by quartering. In an area of 10 by $10 \mathrm{~cm}$, samples were divided into 4 , and opposite sectors eliminated, repeating the process until obtaining $2 \mathrm{~g}$ of sample. Reactor $\mathrm{C}$ sample components, wood chips and limestone, required manual separation first.

The samples of reactive material and sediments were dried at $60^{\circ} \mathrm{C}$ (binder) to constant mass. Then, $1 \mathrm{~g}$ of the dry sample was ground and digested for $24 \mathrm{~h}$ at $60^{\circ} \mathrm{C}$ (C-MAG HS7, IKA) with nitric acid at $65 \%$ (Suprapur, Merck, Darmstadt, Germany). The temperature was increased to $120^{\circ} \mathrm{C}$ for $1 \mathrm{~h}$, and then kept at $180^{\circ} \mathrm{C}$ until a concentrate of approximately $5 \mathrm{~mL}$ was obtained, which was allowed to cool to $\pm 60^{\circ} \mathrm{C}$, and then digestions were carried out with perchloric acid at $70 \%$ (Suprapur, Merck, Darmstadt, Germany) for $30 \mathrm{~min}$ at $220^{\circ} \mathrm{C}$. The residuum was cooled to ambient temperature and diluted to $100 \mathrm{~mL}$ with deionized water to determine the $\mathrm{Cu}, \mathrm{Zn}, \mathrm{Ca}$, and $\mathrm{Al}$ concentrations with AAS (AAnalyst 400, Perkin Elmer, Waltham, USA). Additionally, different samples were analyzed using an X-ray diffractometer (XRD) model D4 ENDEAVOR, Bruker, Madison, USA, with copper radiation to identify the presence of crystalline minerals.

\subsection{Microbiological and Molecular Analysis}

Samples of the effluents of biological bioreactors SDES (A and B) were collected periodically to count viable anaerobic microorganisms. The samples were serially diluted and spread onto MV solid medium (DSMZ 641, DSMZ-German Collection of Microorganisms and Cell Cultures GmbH, Braunschweig, Germany) and incubated in an anaerobic atmosphere (using the Anaerogen ${ }^{\mathrm{TM}}$ system, Oxoid, Basingstoke, $\mathrm{UK}$ ) at $30^{\circ} \mathrm{C}$ for four weeks to determine the colony-forming units (CFU). Individual 
colonies were then subcultured repetitively on fresh solid medium, to confirm the identities of the isolates obtained. Next, individual colonies from each pure culture were resuspended in a basal medium of salts to extract DNA (typically $1 \mu \mathrm{L}$ ) for the amplification of the 16S rRNA gene [34] using the primer pairs 27F [35] and 1492R [36]. The PCR products were sequenced (Macrogen, Inc., Seoul, South Korea) and aligned using the BLASTN online software (NCBI) and compared with the GenBank database [37].

\section{Results}

\subsection{Effluent Hydrochemistry}

\subsubsection{Sulfate Removal}

The biochemical reactors achieved high sulfate removals (Figure 2a,b). During phase 2 of continuous sulfated solution feeding, the sulfate reduction rates averaged 0.25 and $0.37 \mathrm{~mol} \mathrm{~m}^{-3} \mathrm{day}^{-1}$ for SDES A and B reactors, respectively. Later, during stage 3 of AMD feeding, they averaged 0.27 and $0.29 \mathrm{~mol} \mathrm{~m}^{-3}$ day $^{-1}$. Therefore, the DES system provided a significant degree of protection to microorganisms since the reduction rates were not significantly affected once the AMD feeding began. However, during the last three months of stage 3, the sulfate reduction rates decreased to 0.17 and $0.21 \mathrm{~mol} \mathrm{~m}^{-3}$ day $^{-1}$ (Figure $2 \mathrm{~b}$ ), perhaps due to the depletion of the more bioavailable organic matter. On the other hand, the DAS reactor only removed 0.061 moles $\mathrm{SO}_{4} \mathrm{~m}^{-3} \mathrm{~d}^{-1}$, and the ADES reactor, 0.059 moles $\mathrm{SO}_{4} \mathrm{~m}^{-3} \mathrm{~d}^{-1}$, due to the high solubility of sulfate salts. The only significant sulfate removal reaction in chemical reactors is gypsum precipitation, in association with limestone grains $[4,31]$.

\subsubsection{Chemical and Biological Process Indicators (ORP, $\mathrm{pH}$, Sulfide, Calcium)}

During the acclimatization process (phase 1) and the continuous feeding of sulfate-bearing solution (phase 2), sulfide was the main indicator of biological activity (Figure 2c), while during the rest of the experiment its levels were close to zero, indicating the precipitation of metallic sulfides (phase 3) and an excess metal to sulfide ratio. On the other hand, effluent calcium (Figure 2d) in chemical reactors accounted for the reactions of limestone dissolution and gypsum precipitation.

Effluent $\mathrm{pH}$ (Figure 2e) of SDES reactors stabilized between 4.5 and 5.5 during AMD feeding. Preferential flow paths due to initial differential substrate compaction may explain the small differences between biological prototypes. Instead, effluent $\mathrm{pH}$ in DAS and ADES reactors ranged from 6.5 to 7 , as a result of increased buffering by calcite solids.

The redox potential (ORP) is a measure of how reducing or oxidizing an environment is. Free sulfide in SDES prototypes A and B, during phases 1 and 2, reduced the ORP to $<-200 \mathrm{mV}$ (Figure 2f), optimal for biological sulfate reduction [6]. However, the reaction of sulfide with metals $(\mathrm{Cu}, \mathrm{Zn}$, and $\mathrm{Fe}$ ) during AMD feeding resulted in positive ORP values and an oxidizing environment. Notwithstanding, substrate ORP remained negative and $\mathrm{pH}$ values were higher, as measurements at a depth of $40 \mathrm{~cm}$ at the end of the experiment showed $(-200 \mathrm{mV}<\mathrm{ORP}<-60 \mathrm{mV} ; 5.8<\mathrm{pH}<7.6)$. Finally, in the chemical reactors, ORP values remained always in the positive range, due to the absence of a reducing agent. 

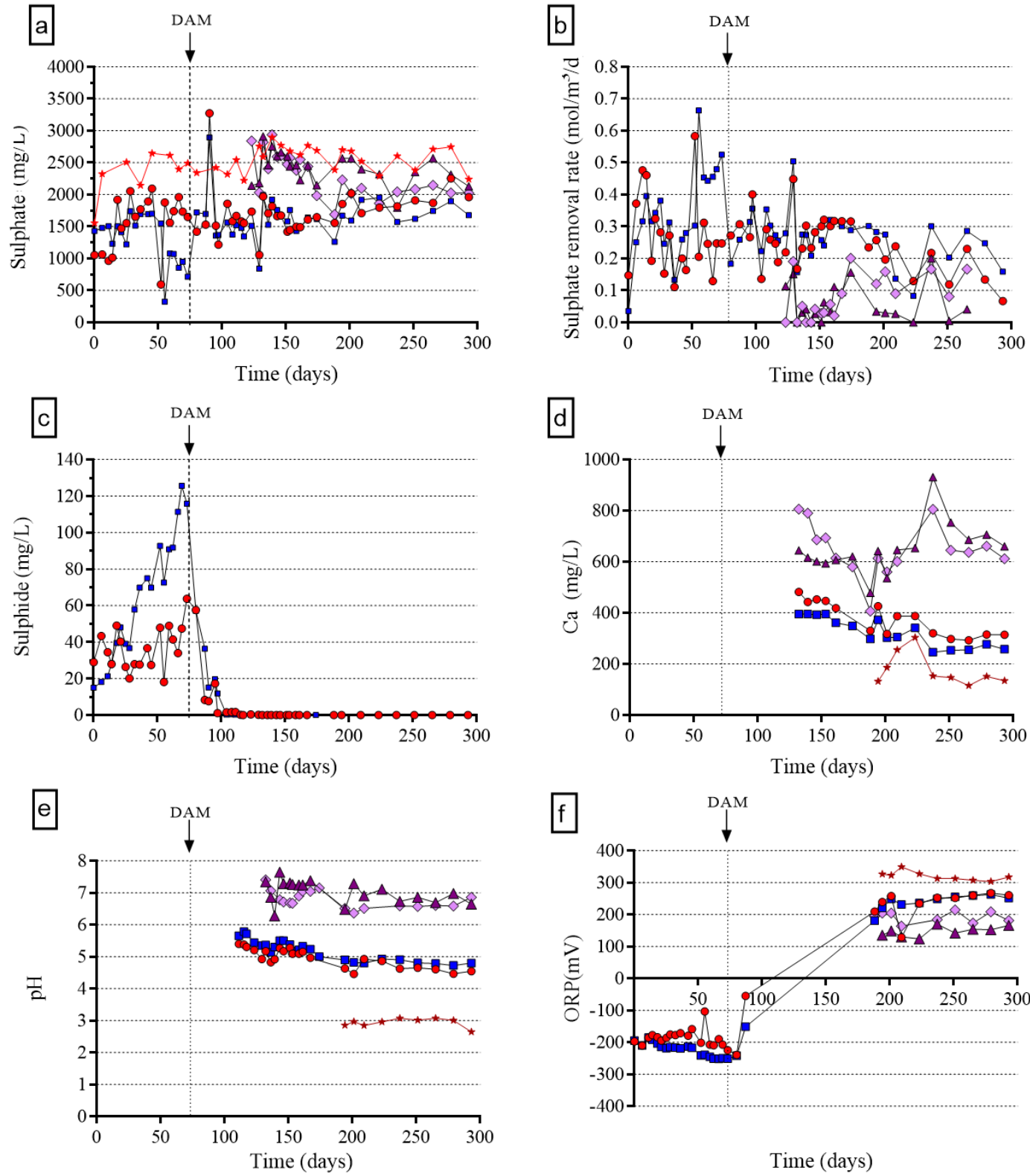

Time (days)

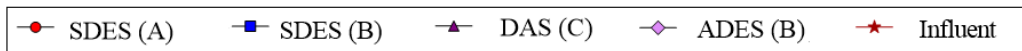

Figure 2. Evolution of critical variables during the experiment: (a) effluent sulfate; (b) sulfate removal rate; (c) effluent sulfide; (d) effluent calcium; (e) effluent $\mathrm{pH}$; (f) effluent $\mathrm{ORP}\left(\mathrm{E}_{\mathrm{Ag} / \mathrm{AgCl}}\right)$.

\subsubsection{Metal Removal}

Figure 3 shows effluent metal concentrations during AMD feeding and Table 2 individual and total metal removal rates and efficiencies. Average metal removal rates in reactors A and B reached 326.6 and $310.8 \mathrm{mmol} \mathrm{m}^{-3}$ day $^{-1}$, respectively, values considered normal for biochemical reactors [5]. Nevertheless, metal removal was only partial because the metal load was higher than generated sulfide (evidenced by the low levels of effluent sulfide). Notably, low $\mathrm{Zn}$ and Mn removals are explained by the high solubility product of $\mathrm{ZnS}\left(10^{-24.7}\right)$ compared to $\mathrm{CuS}\left(10^{-36.1}\right)$, while Mn does not form MnS solids (Figure 3 and Table 2). Instead, the chemical reactors achieved close to 100\% metal removal, less for $\mathrm{Mn}$, because even chemical calcite-based passive reactors do not generate sufficiently high $\mathrm{pH}$ values required for adequate $\mathrm{Mn}$ precipitation [32,38]. 

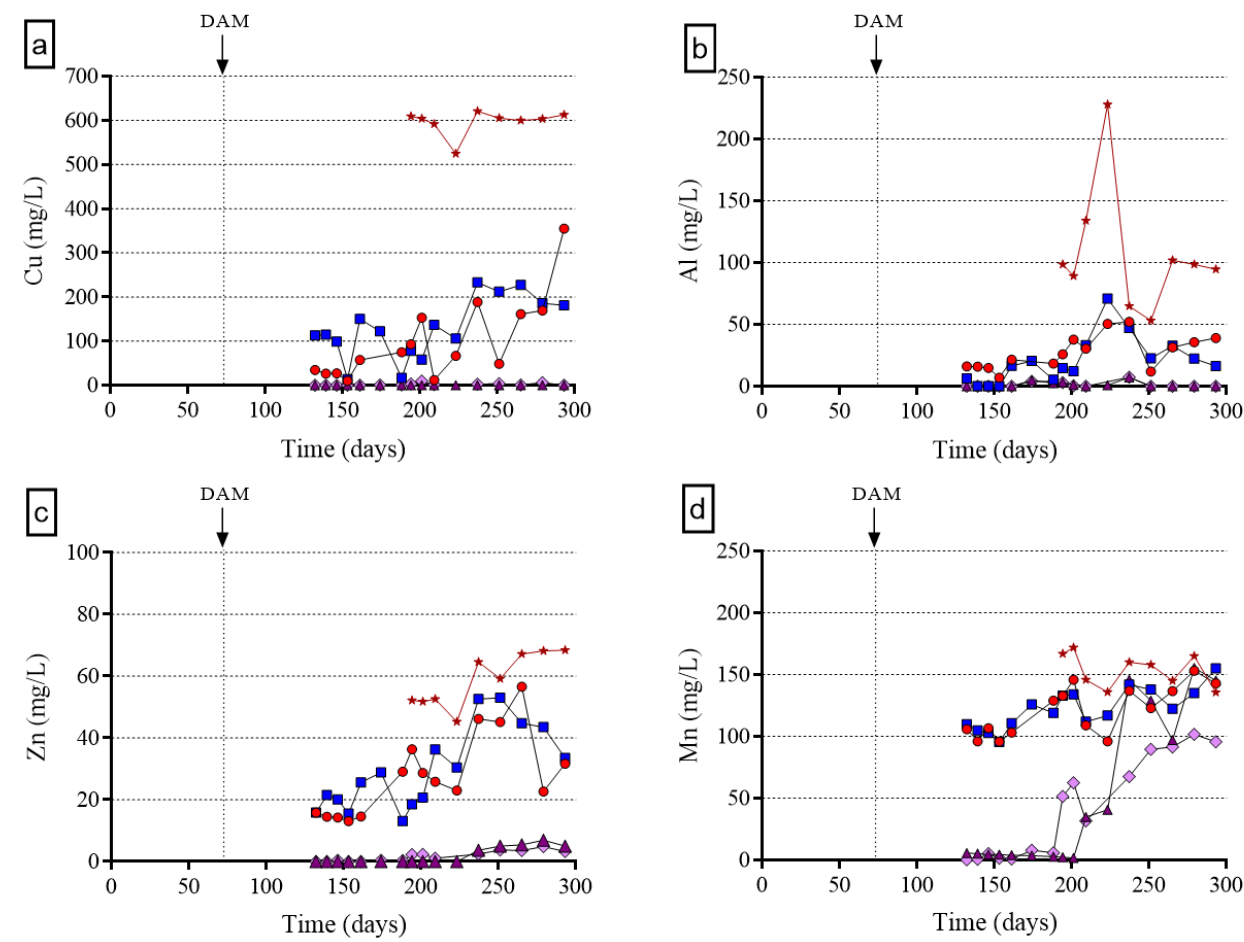

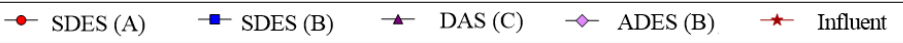

Figure 3. Metal concentrations: (a) $\mathrm{Cu}$; (b) $\mathrm{Al}$; (c) $\mathrm{Zn}$; (d) Mn.

Table 2. Metal removal.

\begin{tabular}{cccccc}
\hline Reactor & Cu & Al & Zn & Mn & Total \\
\hline \multicolumn{7}{c}{ Rates $\left(\mathrm{mmol} \mathrm{m}^{-3}\right.$ day $\left.^{-1}\right)$} \\
\hline SDES A & $213.3 \pm 40.7$ & $76.7 \pm 32.8$ & $14.1 \pm 5.0$ & $22.5 \pm 11.4$ & $326.6 \pm 35.3$ \\
SDES B & $197.1 \pm 24.2$ & $79.9 \pm 26.5$ & $12.8 \pm 5.1$ & $21.0 \pm 7.9$ & $310.8 \pm 22.9$ \\
DAS C & $221.2 \pm 19.8$ & $88.1 \pm 30.3$ & $21.0 \pm 3.0$ & $48.3 \pm 24.6$ & $378.6 \pm 21.9$ \\
ADES D & $245.9 \pm 19.2$ & $97.2 \pm 32.2$ & $23.3 \pm 3.4$ & $55.0 \pm 17.0$ & $421.4 \pm 21.0$ \\
\hline \multicolumn{7}{c}{ Total removed (moles) and efficiencies (in parenthesis) } \\
\hline SDES A & $1.26(87 \%)$ & $0.47(80 \%)$ & $0.09(66 \%)$ & $0.19(45 \%)$ & $2.02(80 \%)$ \\
SDES B & $1.18(82 \%)$ & $0.47(82 \%)$ & $0.08(60 \%)$ & $0.18(41 \%)$ & $1.91(77 \%)$ \\
DAS C & $1.41(100 \%)$ & $0.57(99 \%)$ & $0.14(98 \%)$ & $0.31(73 \%)$ & $2.42(95 \%)$ \\
ADES D & $1.43(100 \%)$ & $0.57(99 \%)$ & $0.14(98 \%)$ & $0.32(76 \%)$ & $2.46(96 \%)$ \\
\hline
\end{tabular}

\subsection{Reactor Hydrochemical Profiles (DAS and ADES Only)}

Figure 4 shows a sequence of hydrochemical profiles within chemical reactors, based on measurements in samples at intermediate ports. The $\mathrm{pH}$ behavior within reactors (Figure $4 \mathrm{a}, \mathrm{f}$ ) was uniform over most of the substrate, with the highest $\mathrm{pH}$ increase constrained to the first $20 \mathrm{~cm}$ in the DAS, and to the first $10 \mathrm{~cm}$ in the ADES. Slower calcite dissolution kinetics due to passivation may explain the slower $\mathrm{pH}$ increase rate in the DAS.

The dynamics of the dissolved Ca profile evolution inside the reactors were complex. Dissolved Ca in the DAS had the expected behavior by decreasing initially, consistent with limestone depletion [29], while the more constant dissolved Ca profiles in the ADES (Figure 4i) could be due to reduced passivation or to diffusion-limited lateral transport, as reaction products such as $\mathrm{Ca}^{2+}$ must diffuse laterally to the central screen before being removed by advective flow. Similar behavior was not observed in the $\mathrm{pH}$ profiles (Figure 4f), perhaps due to the higher diffusivity of the $\mathrm{H}^{+}$ion. Also, both reactors maintained an effluent $\mathrm{Ca}$ concentration in a narrow range of $600-650 \mathrm{mg} \mathrm{L}^{-1}$, perhaps conditioned by a solubility limit. 
Similar behavior of $\mathrm{Cu}, \mathrm{Zn}$ and $\mathrm{Mn}$ were observed between reactors. $\mathrm{Cu}$ also slowed down $\mathrm{Zn}$ removal in the chemical reactors as $\mathrm{Cu}$ was removed first (Figure $4 \mathrm{~b}, \mathrm{~g}$ ) and $\mathrm{Zn}$, mainly between 40 to $60 \mathrm{~cm}$ (Figure 4c,h). Again, Mn breakthrough was fast in both reactors (Figure 4e,j). Finally, lower initial $\mathrm{Cu}$ and $\mathrm{Zn}$ concentrations within the ADES can also be explained by lateral diffusion-controlled transport.

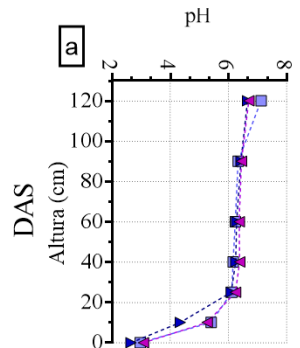

$\mathrm{pH}$

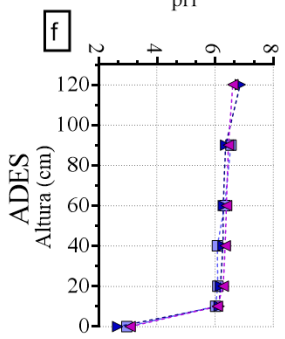

$\mathrm{Cu}(\mathrm{mg} / \mathrm{L})$

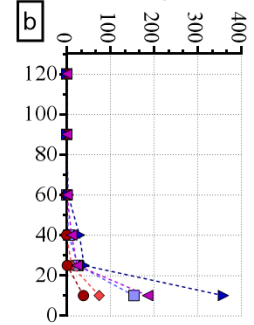

$\mathrm{Cu}(\mathrm{mg} / \mathrm{L})$

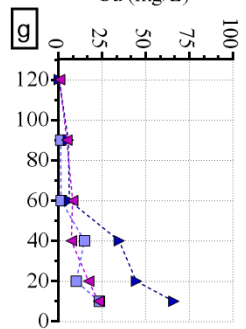

$\mathrm{Zn}(\mathrm{mg} / \mathrm{L})$

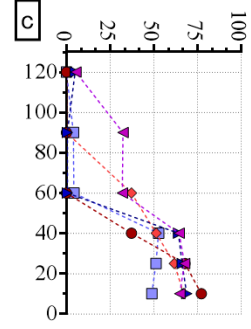

$\mathrm{Zn}(\mathrm{mg} / \mathrm{L})$

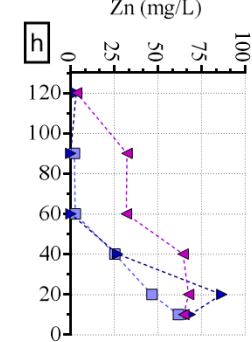

$\mathrm{Ca}(\mathrm{mg} / \mathrm{L})$

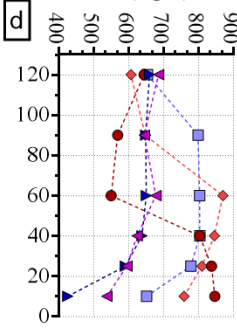

$\mathrm{Ca}(\mathrm{mg} / \mathrm{L})$

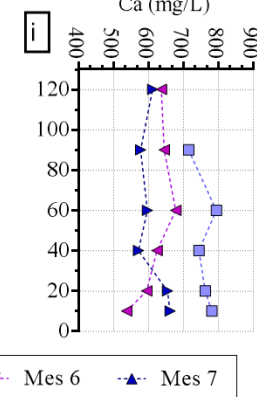

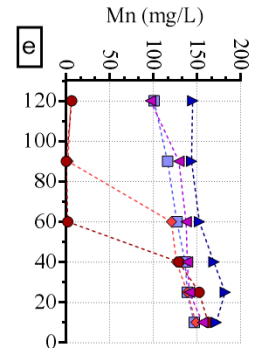

$\mathrm{Mn}(\mathrm{mg} / \mathrm{L})$

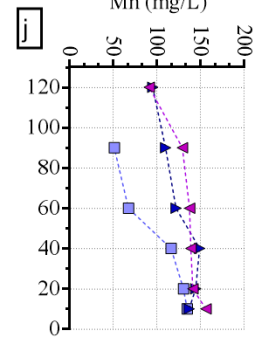

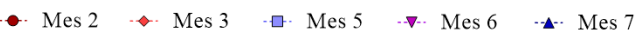

Figure 4. Metal concentration (Cu, Zn, Ca and Mn) profiles for C-DAS (a-e) and D-ADES (f-je reactors.

\subsection{Metal Accumulation in Reactors}

Figure 5 shows the distribution of concentrations of $\mathrm{Ca}, \mathrm{Cu}, \mathrm{Al}$, and $\mathrm{Zn}$ in the reactive bed of the reactors at the end of the experiment. In the biochemical reactors, the layer surrounding the screen $(0-1.5 \mathrm{~cm})$ presented the highest concentrations of $\mathrm{Cu}, \mathrm{Al}$, and $\mathrm{Zn}$. Also, metal concentrations were highest in the first $0-10 \mathrm{~cm}$ zone of the columns, showing a diminishing trend toward the final zone, similar to what was observed in chemical reactors. Notably, the reactive area in contact with the central screen acquired a black-blue color, which is interpreted as due to sulfur-containing metals generated from the activity of SRB, such as copper or iron sulfide [18]. As explained by the diffusive exchange model [26], the precipitates accumulate inside the reactor near the interface between the reactive and conductive zones where cross-sectional fluxes of metals and biogenic sulfide meet.

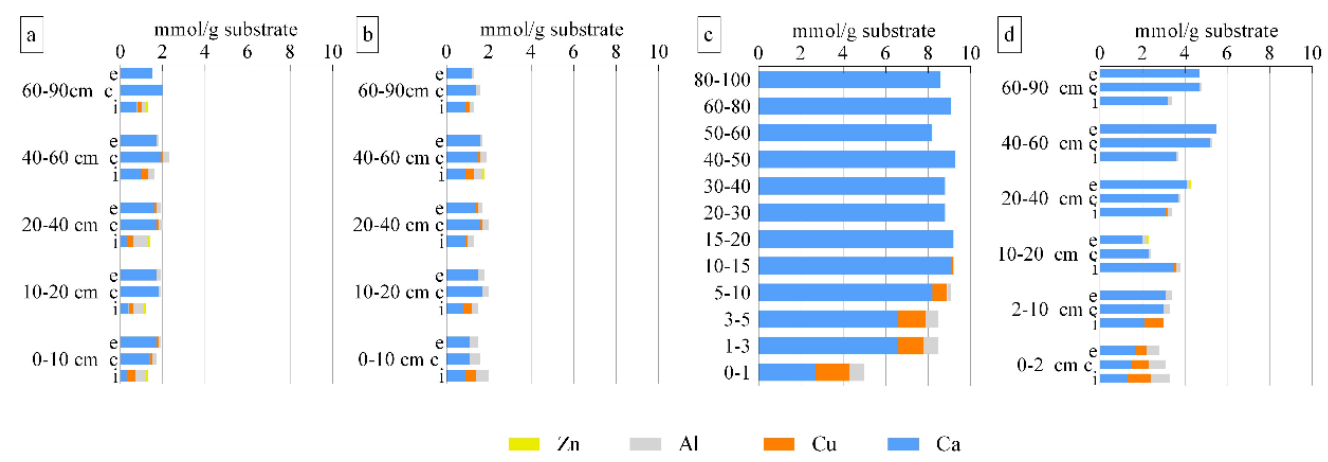

Figure 5. Chemical composition of the solid samples versus height in reactors: (a) A-SDES; (b) B-SDES; (c) C-DAS; (d) D-ADES. In DES reactors (A, B, and C) " $\mathrm{i}$ " stands for the inner annular section $(0-1.5 \mathrm{~cm})$ next to the screen, " $\mathrm{m}$ " for the middle annular section $(1.5-3.5 \mathrm{~cm})$, and " $\mathrm{e}$ " for the outer or exterior annular section $(3.5-6.5 \mathrm{~cm})$. 
The areas with the highest dissolution of $\mathrm{CaCO}_{3}$ and, therefore, with the lowest presence of $\mathrm{Ca}$ in the solid phase coincided with those with the highest accumulation of AMD metals. Thus, the reaction of AMD with calcite was also a significant mechanism of metal immobilization in biochemical reactors. SDES reactors did not experiment clogging, in contrast to conventional biochemical reactors that are vulnerable to permeability losses due to the accumulation of metallic precipitates and organic growth in the pores, especially for operations at high HRT [14].

In chemical reactors $C$ (DAS) and D (ADES), no copper was detected in the effluent, and the influent copper was accounted for by precipitated copper on the substrate, mostly in the first $0-10 \mathrm{~cm}$ layer (Figure $5 \mathrm{c}, \mathrm{d}$ ). In the DAS, a thick cemented shell (hardpan) formed, capable of clogging the reactor (Figure 6). The shell was formed mainly by calcite, wood chips and blue-turquoise precipitates characteristic of carbonates, hydroxides and copper sulfates. Rötting et al. [31] confirmed that aluminum was responsible for clogging in their DAS reactors and that gypsum was responsible for passivating the surface of the calcite grains. Here, there was also evidence of passivation due to the only partial dissolution of calcite, reaching a maximum of $69 \%$ in the first centimeter of the DAS substrate (Figure $5 \mathrm{c}$ ). Unlike the DAS, the first layer of substrate in the ADES was only partially cemented by precipitates (Figure 7), and because of the screen, clogging was not an issue. Broader internal distribution of $\mathrm{Cu}$ precipitates was evidenced, forming near the interface between the conductive and reactive zones. Armoring may have also occurred in the ADES as the maximum Ca dissolution detected was $73 \%$.
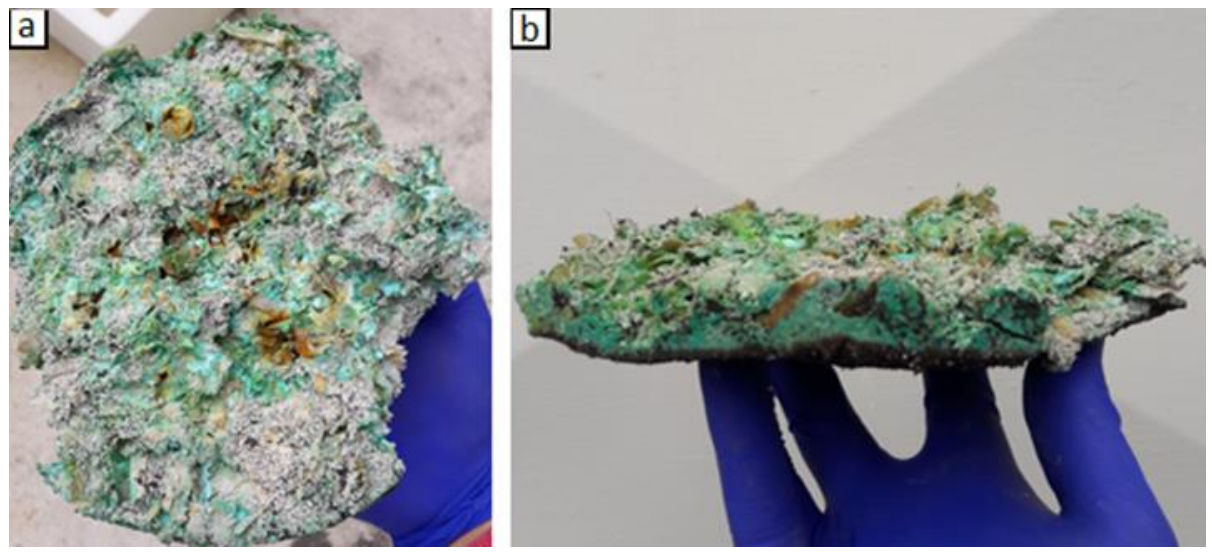

Figure 6. Formed in the DAS reactor: (a) front view; (b) side view.
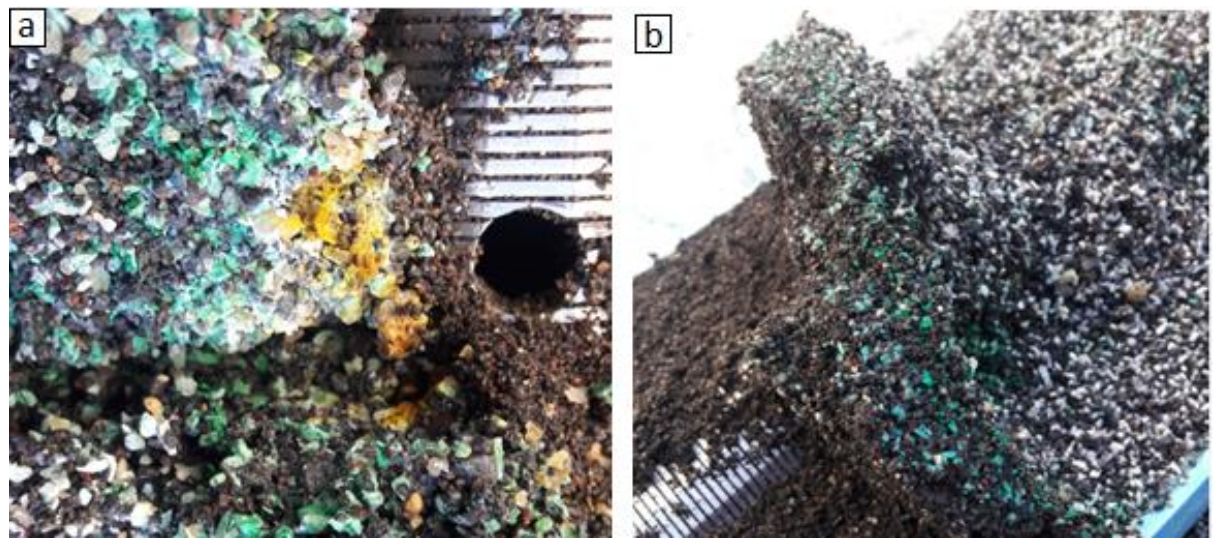

Figure 7. The ADES reactive substrate near the screen: (a) colors of the precipitates; (b) partial armoring.

The chemical reactors concentrated the precipitation reactions in a thin bottom cross-section resulting in a local permeability loss that critically impaired reactor hydraulics of the DAS. Because the reactors were operated in upward flow mode, the clogged layer formed at the bottom and could not be removed to restore substrate permeability. Similarly, a calcite-DAS tested at pilot field-scale formed a 
hardpan of Al-rich precipitates causing clogging or loss of permeability [29], however, the reactor flow was downward and precipitation took place in the uppermost layer. The permeability was restored by excavating the top $10 \mathrm{~cm}$ of substrate. Periodic harvesting of the hardpan could also facilitate valuable metal recovery. On the other hand, considering that precipitates in biochemical reactors accumulated in the layer surrounding the screen, their periodic removal would be impracticable and metal recovery would have to be evaluated during decommissioning.

A detailed study of the fate of $\mathrm{Cu}$ in the reactors was carried out (Figure 8), due to the high concentration of $\mathrm{Cu}$ in the AMD and its potential effect on the reactors' clogging and passivation, as well as to the importance of recovering it. The SDES reactors (A and B) behaved similarly, receiving in average $91.4 \pm 0.6 \mathrm{~g} \mathrm{Cu}$, of which $49 \% \pm 0.4 \%$ deposited in the reactive substrate, $15.1 \% \pm 3.4 \%$ left dissolved and $5.5 \% \pm 0.5 \%$ particulate in the effluent, and $5.2 \% \pm 0.7 \%$ accumulated in the bottom sediment of the screen $(25.5 \% \pm 3.5 \%$ was unaccounted for $)$. In the case of DAS and ADES rectors, estimated recovered $\mathrm{Cu}$ in the substrate $(114.9 \mathrm{~g}$ and $92.4 \mathrm{~g} \mathrm{Cu}$, respectively) was more than influent $\mathrm{Cu}$, giving mass balance errors of $28 \%$ and $2 \%$, respectively. Correspondingly, total effluent $\mathrm{Cu}$ of 0 and $0.3 \mathrm{~g}$ was negligible. Also, only $0.4 \mathrm{~g} \mathrm{Cu}$ was recovered from the bottom of the ADES screen. Reducing the mass balance error of the order of $25 \%$ in SDES reactors would require increasing the transverse sampling resolution, considering the sharp metal gradients that are expected to form [26]. Additionally, the 30\% DAS mass balance error, might be due to the presence of preferential flows in this type of reactors [38], increasing spatial variability.

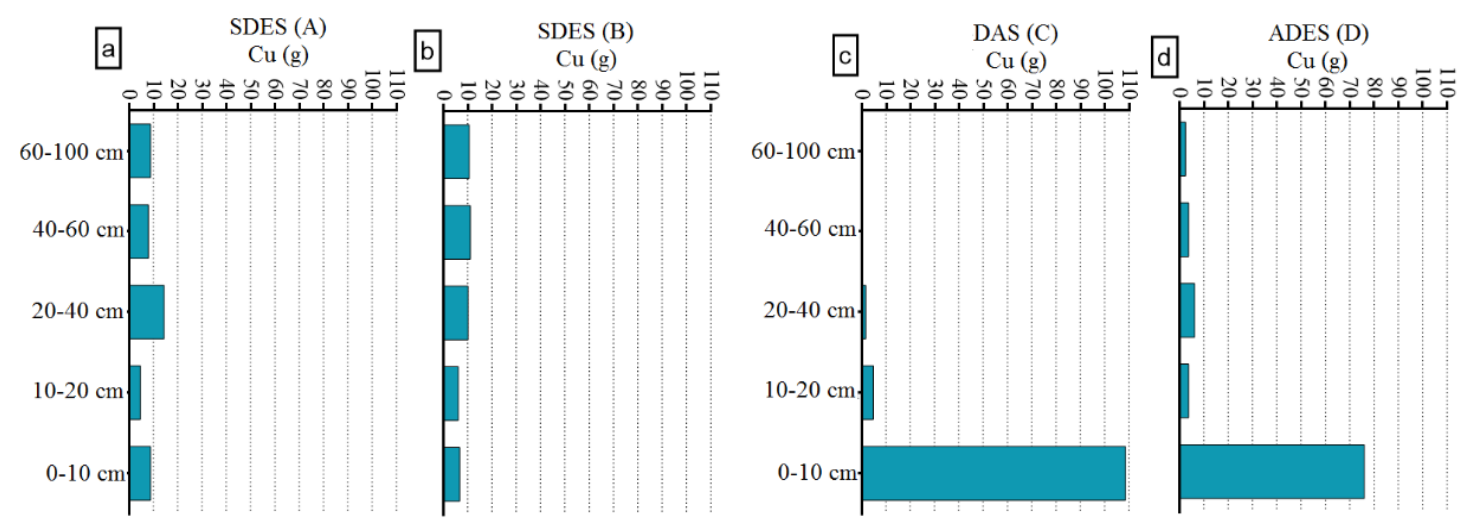

Figure 8. Fate of $\mathrm{Cu}$ in reactors: (a) A-SDES; (b) B-SDES; (c) C-DAS; (d) D-ADES.

\subsection{Post-Treatment Mineralogy (XRD)}

Figure 9 presents the $X$-ray diffractograms of the reactive substrate samples. The identification of minerals depends on the crystallization they achieved. The absence of minerals due to poor crystallinity in XRD readings is recorded in several studies $[39,40]$. The XRD peaks of the SDES reactors corresponded mainly to Covellite (CuS) and Wurtzite (ZnS) minerals. For the DAS and ADES reactors, Malachite signals $\left(\mathrm{Cu}_{2} \mathrm{CO}_{3}(\mathrm{OH})_{2}\right)$ were observed, without finding any other copper mineral. No zinc or aluminum minerals were recorded either. Similarly, Gibert et al. [39] recorded the presence of malachite inside batch reactors composed of calcite with similar $\mathrm{pH}$ and fed with copper, but unlike our records, they found paratacamite $\left(\mathrm{Cu}_{2}(\mathrm{OH})_{3} \mathrm{Cl}\right)$. Finally, in all the reactors peaks corresponding to the minerals calcite $\left(\mathrm{CaCO}_{3}\right)$ and gypsum $\left(\mathrm{CaSO}_{4} \cdot \mathrm{H}_{2} \mathrm{O}\right)$ were observed, the first present in the substrate mixture, and the second, formed by supersaturation due to the supply of influent sulfate, and the release of $\mathrm{Ca}$ by calcite dissolution. 

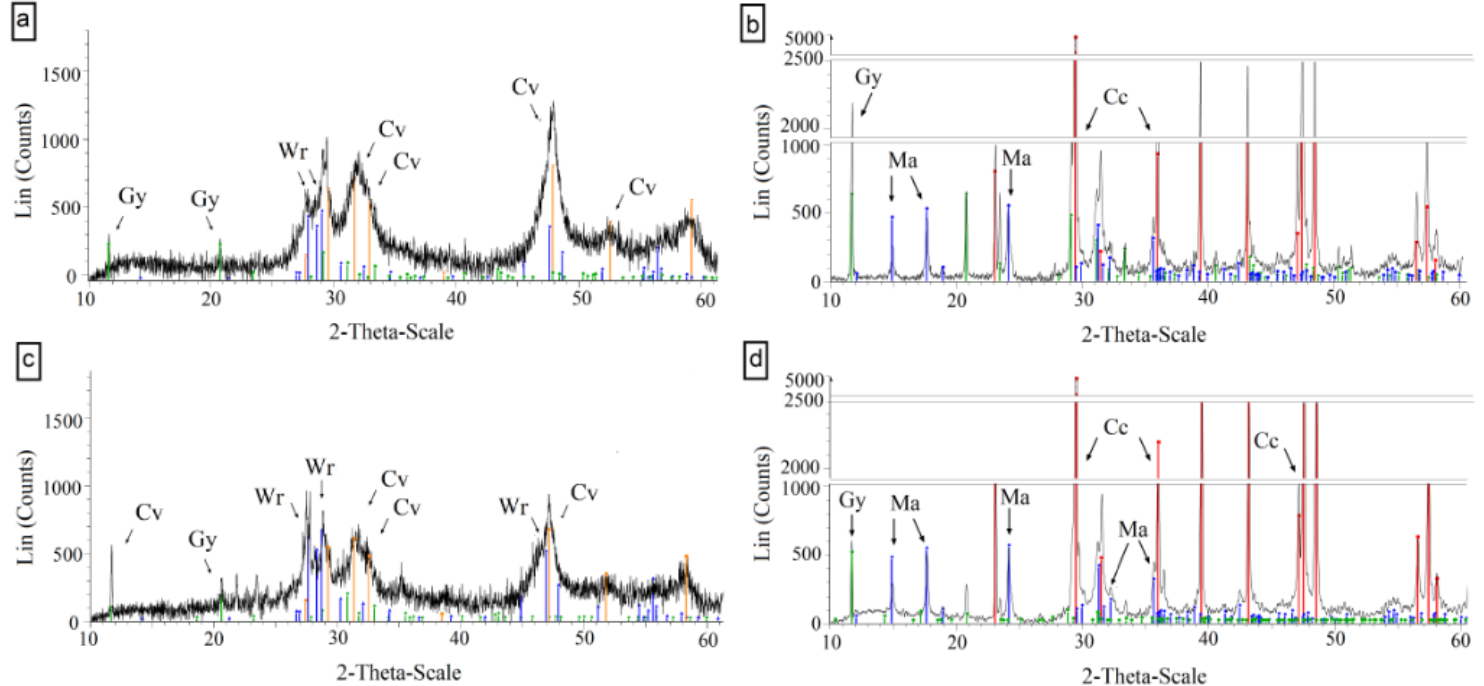

$$
\begin{array}{lll}
\text { Gy: Gypsum } & \mathrm{CaSO}_{4} \mathrm{H}_{2} \mathrm{O} & \mathrm{Cc}: \text { Calcite } \mathrm{CaCO}_{3} \\
\text { Cv: Covelite } & \mathrm{CuS} & \text { Ma: Malachite } \mathrm{Cu} 2\left(\mathrm{CO}_{3}\right)(\mathrm{OH})_{2}
\end{array}
$$

Figure 9. Diffractograms of precipitates sampled from the inside of reactors: (a) A-SDES; (b) B-SDES; (c) C-DAS; (d) D-ADES.

\subsection{Microbiological Changes in the Bioreactors}

\subsubsection{Evolution of CFU Counts}

The SDES bioreactors showed a progressive tendency to decrease CFU, during the continuous operation with AMD feed (Figure 10), particularly during days 30 and 215, probably as a consequence of the concentrations of $\mathrm{Cu}$ and $\mathrm{Zn}$ present in the bioreactors, above the inhibitory levels for the SRB (4 and $13 \mathrm{mg} \mathrm{L}^{-1}$ respectively; Kaksonen and Puhakka [41]). Besides, Utgikar et al. [42] determined that metal sulfide precipitates are also potentially inhibitory to SRBs. The same toxic effect has been recently reported by Torregrosa et al. [9] using passive bench-scale reactors with diffusive exchange systems, where the mechanism of bioprotection with different reactive layer thicknesses was studied. However, it should be noted that the CFU determined in this study are correlated with the number of cells present in the effluent, therefore this trend might not represent the predominant activity in the reactive material packed in the columns. Furthermore, the diffusive exchange bioreactors are also characterized by an area of low hydraulic conductivity, where the sulfidogenic consortiums grow efficiently by minimizing the contact with the soluble metal in the screen.

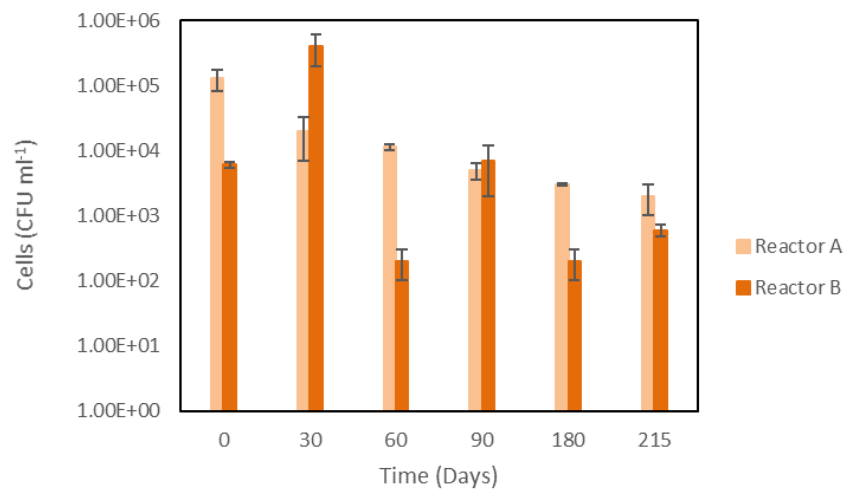

Figure 10. Monitoring of the anaerobic microbial population in SDES biological bioreactors (A and B) operated in continuous flow mode with AMD feeding. 


\subsubsection{Identification of Bacterial Isolates}

Four isolates were obtained during the operation with synthetic AMD feeding (Table 3). One of these isolates (UDEC_USS ASMT5 isolate) was confirmed to belong to the SRB group, responsible for the production of sulfides in the bioreactors, while the other three isolates did not present evidence of sulfidogenesis. The first isolate and the predominant culturable bacteria in effluent samples (between 55-70\%; data not shown) corresponded to the neutrophilic sulfate-reducing species Desulfovibrio marrakechensis, which has been reported in other sulfidogenic reactors for the treatment of AMD [43-45]. The second isolate was a facultative anaerobic species of the genus Streptococcus, which has been reported within the microbial diversity present in an anaerobic sulfate-reducing bioreactor [46]. The third isolate was the species Brevundimonas mediterranea which is characterized by using cellobiose, a disaccharide that is generated from the hydrolysis of cellulose, acting as an intermediary in the hydrolytic stage of anaerobic digestion [47]. The fourth isolate belongs to the phylum Bacteroidetes encompassing a large number of Gram-negative and anaerobic bacteria with a wide distribution in the environment, including soil, sediments, seawater and the digestive tract of animals. This phylum includes species of the genus Bacteroides [48] that have been identified in other sulfidogenic reactors for the treatment of AMD [6,24,45,49]. Additionally, species of the genus Bacteroides have been reported with the ability to degrade the cellulolytic material [50] and to act as intermediaries in the hydrolysis stage, in anaerobic digestion [47].

The biodiversity obtained during the experiment can be explained by the complex microbial relationship that must exist to degrade insoluble organic complexes to low molecular weight soluble ones such as lactate and organic acids, sources of carbon and electrons bioavailable for SRBs. Also, the existing microbial diversity is favored by the configuration of the bioreactors that prevents the microorganisms from coming into direct contact with the AMD. This protection favors a greater bacterial diversity and, consequently, a higher production of sulfide [6,9] increasing the resilience of the reactor to toxic metal stress, temperature, acidity and exposure to oxygen present in AMD [51].

Table 3. Some physiological and phylogenetic characteristics of the bacteria isolated during the operation of both bioreactors.

\begin{tabular}{|c|c|c|c|c|c|}
\hline Isolate & $\begin{array}{l}\text { Main Physiological } \\
\text { Characteristics }\end{array}$ & $\begin{array}{l}\text { Amplified } \\
\text { Product } \\
\text { Length (nt) } \\
\text { (16S rRNA } \\
\text { gene) }\end{array}$ & Closest Relative & $\begin{array}{l}\text { Similarity } \\
(\%)\end{array}$ & $\begin{array}{r}\text { GenBank } \\
\text { Accession } \\
\text { Number }\end{array}$ \\
\hline $\begin{array}{l}\text { UDEC_USS } \\
\text { ASMT5 16S }\end{array}$ & $\begin{array}{l}\text { Strictly anaerobic, } \\
\text { non-motile and } \\
\text { Gram-negative [52] }\end{array}$ & 1384 & $\begin{array}{c}\text { Desulfovibrio } \\
\text { marrakechensis strain } \\
\text { EMSSDQ4 [52] }\end{array}$ & 99 & MK225576 \\
\hline $\begin{array}{l}\text { UDEC_USS } \\
\text { ASMT6 16S }\end{array}$ & $\begin{array}{c}\text { Gram-positive, } \\
\text { nonspore-forming and } \\
\text { facultative anaerobe [53] }\end{array}$ & 1363 & $\begin{array}{c}\text { Streptococcus } \\
\text { sanguinis strain: JCM } \\
5708\end{array}$ & 99 & MK226162 \\
\hline $\begin{array}{l}\text { UDEC_USS } \\
\text { ASMT7 16S }\end{array}$ & $\begin{array}{c}\text { Gram-negative, } \\
\text { rod-shaped, } \\
\text { non-spore-forming [54] }\end{array}$ & 1302 & $\begin{array}{l}\text { Brevundimonas } \\
\text { mediterranea strain } \\
\text { V4.BO [54] }\end{array}$ & 99 & MK226198 \\
\hline $\begin{array}{l}\text { UDEC_USS } \\
\text { ASMT8 16S }\end{array}$ & Gram-negative [48] & 1361 & $\begin{array}{c}\text { Bacteroidetes } \\
\text { bacterium }\end{array}$ & 94 & MK228862 \\
\hline
\end{tabular}

\section{Conclusions}

- The DES technology showed a good performance in the chemical and biological treatment of AMD, eliminating clogging problems, contributing to increasing the useful life of the ADES reactor, and controlling the harmful effects of metals, favoring the establishment of a diverse community of microorganisms in the SDES reactors. 
- Due to the high reactivity of its substrate, the DAS reactor accumulated the metals in a lower reactor volume, allowing to conclude that it requires the lowest HRT and smallest substrate volume among all reactor types.

- A side effect of this concentration of precipitates in the DAS, however, was the creation of a hardpan layer that caused a significant loss of hydraulic conductivity. Periodic harvesting (removal) of the hardpan could facilitate metal recovery and restore substrate permeability.

- The study indicates that the limitations of each treatment could be overcome by combining their strengths in a combined or serial treatment, such as introducing screen tubes in DAS reactors to overcome clogging problems.

Author Contributions: Conceptualization, A.S.; formal analysis, I.N., P.S. and M.T.; funding acquisition, A.S.; investigation, M.A.G., D.M. and M.T.; methodology, A.S., P.S. and M.A.; project administration, A.S. and P.S.; resources, I.N., T.R., and G.S.; supervision, A.S.; writing-original draft, A.S., I.N., M.A.G., D.M., P.S. and M.T.; writing-review and editing, I.N., T.R., G.S. and M.A. All authors have read and agreed to the published version of the manuscript.

Funding: This research was funded by CONICYT, grant numbers FONDECYT 1140451 and FONDECYT 11150170.

Conflicts of Interest: The authors declare no conflict of interest.

\section{References}

1. Ayora, C.; Nieto, J.-M.; Rötting, T.S.; Caraballo, M.A.; Carrera, J.; Macias, F. Acid mine drainage in the Iberian Pyrite Belt: 2. Lessons learned from recent passive remediation experiences. Environ. Sci. Pollut. Res. 2013, 20, 7837-7853. [CrossRef] [PubMed]

2. Hallberg, K.B. New perspectives in acid mine drainage microbiology. Hydrometallurgy 2010, 104, 448-453. [CrossRef]

3. Simate, G.S.; Ndlovu, S. Acid mine drainage: Challenges and opportunities. J. Environ. Chem. Eng. 2014, 2, 1785-1803. [CrossRef]

4. Rakotonimaro, T.V.; Neculita, C.M.; Bussière, B.; Zagury, G.J. Effectiveness of various dispersed alkaline substrates for the pre-treatment of ferriferous acid mine drainage. Appl. Geochem. 2016, 73, 13-23. [CrossRef]

5. Pérez, N.; Schwarz, A.; Sanhueza, P.; Chaparro, G. Performance of three bench-scale diffusive exchange systems during treatment of acid mine drainage with high copper concentration. Desalin. Water Treat. 2017, 64, 21-30. [CrossRef]

6. Pérez, N.; Schwarz, A.; Barahona, E.; Sanhueza, P.; Diaz, I.; Urrutia, H. Performance of two differently designed permeable reactive barriers with sulfate and zinc solutions. Sci. Total Environ. 2018, 642, 894-903. [CrossRef]

7. Pino, L.; Vargas, C.; Schwarz, A.; Borquez, R. Influence of operating conditions on the removal of metals and sulfate from copper acid mine drainage by nanofiltration. Chem. Eng. J. 2018, 345, 114-125. [CrossRef]

8. Andalaft, J.; Schwarz, A.; Pino, L.; Fuentes, P.; Bórquez, R.; Aybar, M. Assessment and modeling of nanofiltration of acid mine drainage. Ind. Eng. Chem. Res. 2018, 57, 14727-14739. [CrossRef]

9. Torregrosa, M.; Schwarz, A.; Nancucheo, I.; Balladares, E. Evaluation of the bio-protection mechanism in diffusive exchange permeable reactive barriers for the treatment of acid mine drainage. Sci. Total Environ. 2019, 655, 374-383. [CrossRef]

10. Johnson, D.B. Biomining-biotechnologies for extracting and recovering metals from ores and waste materials. Curr. Opin. Biotechnol. 2014, 30, 24-31. [CrossRef]

11. Johnson, D.B.; Hallberg, K.B. Acid mine drainage remediation options: A review. Sci. Total Environ. 2005, 338, 3-14. [CrossRef] [PubMed]

12. Kalin, M.; Fyson, A.; Wheeler, W.N. The chemistry of conventional and alternative treatment systems for the neutralization of acid mine drainage. Sci. Total Environ. 2006, 366, 395-408. [CrossRef] [PubMed]

13. Caraballo, M.A.; Macías, F.; Rötting, T.S.; Nieto, J.M.; Ayora, C. Long term remediation of highly polluted acid mine drainage: A sustainable approach to restore the environmental quality of the Odiel river basin. Environ. Pollut. 2011, 159, 3613-3619. [CrossRef] [PubMed] 
14. Neculita, C.M.; Zagury, G.J.; Bussière, B. Effectiveness of sulfate-reducing passive bioreactors for treating highly contaminated acid mine drainage: II. Metal removal mechanisms and potential mobility. Appl. Geochemistry 2008, 23, 3545-3560. [CrossRef]

15. ITRC (Interstate Technology \& Regulatory Council). Biochemical Reactors for Mining Influenced Water. BCR-1; Biochemical Reactors for Mining-Influenced Waste Team: Washington, DC, USA, 2013.

16. Jage, C.R.; Zipper, C.E.; Noble, R. Factors affecting alkalinity generation by successive alkalinity-producing systems. J. Environ. Qual. 2010, 30, 1015-1022. [CrossRef]

17. Neculita, C.M.; Zagury, G.J. Biological treatment of highly contaminated acid mine drainage in batch reactors: Long-term treatment and reactive mixture characterization. J. Hazard. Mater. 2008, 157, 358-366. [CrossRef]

18. Vasquez, Y.; Neculita, C.M.; Roldan, F.; Escobar, M.C.; Arbeli, Z. Selection of reactive mixture for biochemical passive treatment of acid mine drainage. Environ. Earth Sci. 2016, 75, 576-587. [CrossRef]

19. Zagury, G.J.; Kulnieks, V.I.; Neculita, C.M. Characterization and reactivity assessment of organic substrates for sulfate-reducing bacteria in acid mine drainage treatment. Chemosphere 2006, 64, 944-954. [CrossRef]

20. Neculita, C.-M.; Zagury, G.J.; Bussière, B. Passive treatment of acid mine drainage in bioreactors using sulfate-reducing bacteria. J. Environ. Qual. 2007, 36, 1-16. [CrossRef]

21. USEPA (United States Environmental Protection Agency). Reference Guide to Treatment Technologies for Mining-Influenced Water. EPA 542-R-14-001; Office of Superfund Remediation and Technology Innovation, 2014. Available online: https://www.epa.gov/remedytech/reference-guide-treatment-technologies-mininginfluenced-water (accessed on 12 January 2020).

22. Drennan, D.M.; Almstrand, R.; Lee, I.; Landkamer, L.; Figueroa, L.; Sharp, J.O. Organoheterotrophic bacterial abundance associates with zinc removal in lignocellulose-based sulfate-reducing systems. Environ. Sci. Technol. 2016, 50, 378-387. [CrossRef]

23. Vasquez, Y.; Neculita, C.M.; Roldan, F.; Escobar, M.C.; Saenz, J.S.; Quiceno-Vallejo, M.F.; Arbeli, Z. Effect of hydraulic retention time on microbial community in biochemical passive reactors during treatment of acid mine drainage. Bioresour. Technol. 2017, 247, 624-632. [CrossRef] [PubMed]

24. Rezadehbash, M.; Baldwin, S.A. Core sulphate-reducing microorganisms in metal-removing semi-passive biochemical reactors and the co-occurrence of methanogens. Microorganisms 2018, 6, 16. [CrossRef] [PubMed]

25. Torres, E.; Castillo, J.; Macías, F.; Torres, E.; Ayora, C.; Lozano, A.; Gomez-Arias, A. Passive elimination of sulfate and metals from acid mine drainage using combined limestone and barium carbonate systems. J. Clean. Prod. 2018, 182, 114-123. [CrossRef]

26. Schwarz, A.O.; Rittmann, B.E. The diffusion-active permeable reactive barrier. J. Contam. Hydrol. 2010, 112, 155-162. [CrossRef]

27. Caraballo, M.A.; Macías, F.; Nieto, J.M.; Castillo, J.; Quispe, D.; Ayora, C. Hydrochemical performance and mineralogical evolution of a dispersed alkaline substrate (DAS) remediating the highly polluted acid mine drainage in the full-scale passive treatment of Mina Esperanza (SW Spain). Am. Mineral. 2011, 96, 1270-1277. [CrossRef]

28. Lozano, A.; Ayora, C.; Macias, F.; Nieto, J.M.; Gomez-Arias, A.; Castillo, J.; Heerden, E. Sulfate removal from acid mine drainage: Evaluation of granular $\mathrm{BaCO}_{3}$ with column experiments. Macla 2014, 19, 83-84.

29. Rötting, T.S.; Caraballo, M.A.; Serrano, J.A.; Ayora, C.; Carrera, J. Field application of calcite Dispersed Alkaline Substrate (calcite-DAS) for passive treatment of acid mine drainage with high Al and metal concentrations. Appl. Geochem. 2008, 23, 1660-1674. [CrossRef]

30. Soler, J.M.; Mogollón, J.L.; Tamura, N.; Cama, J.; Kunz, M.; Nico, P.S.; Boi, M.; Ayora, C. The passivation of calcite by acid mine water. Column experiments with ferric sulfate and ferric chloride solutions at $\mathrm{pH} 2$. Appl. Geochem. 2008, 23, 3579-3588. [CrossRef]

31. Rötting, T.S.; Thomas, R.C.; Ayora, C.; Carrera, J. Passive treatment of acid mine drainage with high metal concentrations using dispersed alkaline substrate. J. Environ. Qual. 2008, 37, 1741-1751. [CrossRef]

32. Macías, F.; Caraballo, M.A.; Rötting, T.S.; Pérez-López, R.; Nieto, J.M.; Ayora, C. From highly polluted Zn-rich acid mine drainage to non-metallic waters: Implementation of a multi-step alkaline passive treatment system to remediate metal pollution. Sci. Total Environ. 2012, 433, 323-330. [CrossRef] 
33. APHA. Standard Methods for the Examination of Water and Wastewater; American Water Works Association/American Public Health Association/Water Environment Federation: Denver, CO, USA, 2005.

34. Rowe, O.F.; Sánchez-España, J.; Hallberg, K.B.; Johnson, D.B. Microbial communities and geochemical dynamics in an extremely acidic, metal-rich stream at an abandoned sulfide mine (Huelva, Spain) underpinned by two functional primary production systems. Environ. Microbiol. 2007, 9, 1761-1771. [CrossRef] [PubMed]

35. Lane, D.J. 16S/23S rRNA sequencing. In Nucleic Acid Techniques in Bacterial Systematics; Goodfellow, M., Stackebrandt, E., Eds.; Wiley Publishing: New York, NY, USA, 1991; pp. 115-175.

36. Marchesi, J.R.; Wade, J.R.; Sato, T.; Weightman, A.J.; Martin, T.A.; Fry, J.C.; Hiom, S.J.; Dymock, D.; Wade, W.G. Design and evaluation of useful bacterium-specific PCR primers that amplify genes coding for bacterial $16 \mathrm{~S}$ rRNA. Appl. Environ. Microbiol. 1998, 64, 795-799. [CrossRef] [PubMed]

37. González, D.; Liu, Y.; Villa Gomez, D.; Southam, G.; Hedrich, S.; Galleguillos, P.; Colipai, C.; Nancucheo, I. Performance of a sulfidogenic bioreactor inoculated with indigenous acidic communities for treating an extremely acidic mine water. Miner. Eng. 2019, 131, 370-375. [CrossRef]

38. Caraballo, M.A.; Rötting, T.S.; Silva, V. Implementation of an MgO-based metal removal step in the passive treatment system of Shilbottle, UK: Column experiments. J. Hazard. Mater. 2010, 181, 923-930. [CrossRef]

39. Gibert, O.; De Pablo, J.; Cortina, J.L.; Ayora, C. Municipal compost-based mixture for acid mine drainage bioremediation: Metal retention mechanisms. Appl. Geochem. 2005, 20, 1648-1657. [CrossRef]

40. Caraballo, M.A.; Rötting, T.S.; Nieto, J.M.; Ayora, C. Sequential extraction and DXRD applicability to poorly crystalline Fe- and Al-phase characterization from an acid mine water passive remediation system. Am. Mineral. 2009, 94, 1029-1038. [CrossRef]

41. Kaksonen, A.H.; Puhakka, J.A. Sulfate reduction based bioprocesses for the treatment of acid mine drainage and the recovery of metals. Eng. Life Sci. 2007, 7, 541-564. [CrossRef]

42. Utgikar, V.P.; Harmon, S.M.; Tabak, H.H.; Govind, R.; Chaudhary, N.; Haines, J.R. Inhibition of sulfate-reducing bacteria by metal sulfide formation in bioremediation of acid mine drainage. Environ. Toxicol. 2002, 17, 40-48. [CrossRef]

43. Zhang, J.; Zhang, Y.; Chang, J.; Quan, X.; Li, Q. Biological sulfate reduction in the acidogenic phase of anaerobic digestion under dissimilatory Fe (III)—Reducing conditions. Water Res. 2013, 47, 2033-2040. [CrossRef]

44. Zhao, Y.; Fu, Z.; Chen, X.; Zhang, G. Bioremediation process and bioremoval mechanism of heavy metal ions in acidic mine drainage. Chem. Res. Chin. Univ. 2018, 34, 33-38. [CrossRef]

45. Dar, S.A.; Bijmans, M.F.M.; Dinkla, I.J.T.; Geurkink, B.; Lens, P.N.L.; Dopson, M. Population Dynamics of a Single-Stage Sulfidogenic Bioreactor Treating Synthetic Zinc-Containing Waste Streams. Microb. Ecol. 2009, 58, 529-537. [CrossRef]

46. Briones, A.M.; Daugherty, B.J.; Angenent, L.T.; Rausch, K.D.; Tumbleson, M.E.; Raskin, L. Microbial diversity and dynamics in multi- and single-compartment anaerobic bioreactors processing sulfate-rich waste streams. Environ. Microbiol. 2007, 9, 93-106. [CrossRef]

47. Logan, M.V.; Reardon, K.F.; Figueroa, L.A.; McLain, J.E.; Ahmann, D.M. Microbial community activities during establishment, performance, and decline of bench-scale passive treatment systems for mine drainage. Water Res. 2005, 39, 4537-4551. [CrossRef] [PubMed]

48. Gibiino, G.; Binda, C.; Lopetuso, L.R.; Rizzatti, G.; Gasbarrini, A.; Scaldaferri, F. Exploring Bacteroidetes: Metabolic key points and immunological tricks of our gut commensals. Dig. Liver Dis. 2018, 50, 635-639. [CrossRef] [PubMed]

49. Baldwin, S.A.; Sanei, H.; Hallam, S.; Rezadehbashi, M.; Khoshnoodi, M.; Taupp, M.; Mattes, A. The microbial community of a passive biochemical reactor treating arsenic, zinc, and sulfate-rich seepage. Front. Bioeng. Biotechnol. 2015, 3, 1-13. [CrossRef] [PubMed]

50. Forsberg, C.W.; Beveridge, T.J.; Hellstrom, A. Cellulase and xylanase release from Bacteroides succinogenes and its importance in the rumen environment. Appl. Environ. Microbiol. 1981, 42, 886-896. [CrossRef]

51. Hiibel, S.R.; Reisman, D.J.; Pruden, A.; Breazeal, M.V.R.; Reardon, K.F.; Pereyra, L.P. Effect of organic substrate on the microbial community structure in pilot-scale sulfate-reducing biochemical reactors treating mine drainage. Environ. Eng. Sci. 2011, 28, 563-572. [CrossRef]

52. Chamkh, F.; Qatibi, A.-I.; Besson, S.; El Asli, A.-G.; Sproer, C.; Lemos, P.C.; Reis, M.; Bennisse, R.; Labat, M. Desulfovibrio marrakechensis sp. nov, a 1,4-tyrosol-oxidizing, sulfate-reducing bacterium isolated from olive mill wastewater. Int. J. Syst. Evol. Microbiol. 2009, 59, 936-942. [CrossRef] 
53. Zhu, B.; Macleod, L.C.; Kitten, T.; Xu, P. Streptococcus sanguinis biofilm formation \& interaction with oral pathogens. Future Microbiol. 2018, 13, 915-932. [CrossRef]

54. Abraham, W.R.; Stroempl, C.; Meyer, H.; Lindholst, S.; Moore, E.R.; Christ, R.; Vancanneyt, M.; Tindall, B.J.; Bennasar, A.; Smit, J.; et al. Brevundimonas mediterranea sp. nov, a non-stalked species from the Mediterranean Sea. Int. J. Syst. Bacteriol. 1999, 49, 1053-1073. [CrossRef] 